\title{
Comparison of Granitoid Characteristics West Kalimantan and Karangsambung Based On Mineralogical And Geochemical Aspects
}

\author{
Kevin Setyo Adi Nugroho ${ }^{1, *}$, Iwan Setiawan ${ }^{2}$, Tri Winarno ${ }^{1}$ \\ ${ }^{1}$ Department of Geological Engineering, Diponegoro University, Semarang, Central Java, Indonesia \\ ${ }^{2}$ Research Center for Geothecnology, Indonesian Institute of Science, Bandung, West Java, Indonesia \\ * Corresponding author : kevinadi1611@gmail.com \\ Telp ; +62857-8527-0385 \\ Received: Jul, 272021 ; Accepted: Sept, 132021. \\ DOI: 10.25299/jgeet.2021.6.3.7417

\section{Abstract} \\ Indonesia was included in the ring of fire so that it has various types of tectonic products, one of which is granitoid. Granitoid is very complex \\ rock and many are found in Indonesia. Some of them are found in West Kalimantan and Karangsambung. Basis of the reasearch is there is no \\ research that compares granitoid in two regions. The purpose of this study was to compare rock characteristics and granite petrogenesis of West \\ Kalimantan and Karangsambung. The research method used was collecting data on field, also laboratory analysis of rock samples using a \\ polarization microscope, refraction microscope, and X-Ray Fluorescence analysis. The mineralogical characteristics of each study area tend to be \\ almost the same. The predominant composition of the main minerals is quartz, plagioclase and orthoclase. But specifically the rock samples from \\ West Kalimantan have been altered from phylic-silicification-propylitic. The entire study area contained accessory minerals, namely apatite, zircon, \\ titanite, and for monazite only in the West Kalimantan sample. There was mineralization up to the supergene stage in the presence of the \\ characteristic minerals for the supergene covelite and chalcocytes in the West Kalimantan sample. Geochemical analysis of both regions shows the \\ same magma affinity, namely Calc Alkaline - High K Calc Alkaline. For West Kalimantan, the value of A / CNK <1.1 has a type metaluminious \\ and $>1.1$ a type peraluminious. Meanwhile, Karangsambung A / CNK value $<1.1$ has a type metaluminious. So that West Kalimantan granite has \\ two I-type and S-type. While Karangsambung is I-type. West Kalimantan granite is formed in continental arc granite (CAG) and continental \\ collision granite (CCG). Meanwhile, Karangsambung in Volcanic Arc Granite (VAG). It can be concluded that the granites of the two regions have \\ quite different characteristics even though they belong to a relatively similar tectonic environment.
}

Keywords: Granite, Mineralogy, Geochemical, Petrogenesis, West Kalimantan, Karangsambung.

\section{Introduction}

Indonesia is an archipelagic country surrounded by two oceans, namely the Pacific Ocean and the Indian Ocean, two continents, called the Asian continent and the Australian continent, and is included in the ring of fire. Therefore, the tectonic process greatly affects the product, one of the products of tectonism is granitod. Granite rocks are granular igneous rocks that generally contain quartz and two types of feldspar (Barbarin, 1999). Granitoids are classified into several types based on mineral content, field appearance and petrography as well as chemical characteristics (Streckeisen, 1976; Pearce, Harris and Tindle, 1984; Maniar and Piccoli, 1989; Barbarin, 1999).

The location of the research was carried out in two different area called West Kalimantan and Karangsambung. According to (Ilmawan, 2019) in the West Kalimantan, especially Bengkayang, is included in low to medium sulphide epithermal mineralization, but does not discuss in detail about the rock of origin. Meanwhile, according to (Setiawan and Novian, 2015) Karangsambung granitoid of the Cordilleran type is derived from a normal volcanic arc product and the possibility of a Caledonian type granitoid which is the product of a posttectonic collision of partial melting in the continental crust. Based on (Isyqi, Hastria and Ansori, 2016) classified the tectonic setting of Karangsambung granite into volcanic arc granite (VAG) with metaluminious magma of dominant origin.

The absence of research that compares the characteristics of the granitic rocks of Karangsambung and West Kalimantan is what underlies the authors to conduct research. This study aims to compare the mineralogical and geochemical characteristics of granitic rocks.

\section{Regional Geology}

\subsection{Regional Geologi of West Kalimantan}

According to (Suwarna et al., 1993) who compiled the Geological map of the Singkawang. the research area includes the Sintang intrusion, Mensibau granodiorite and Pueh granite can be seen fig 1. Mensibau Granodiorite (Klm), has a lithology of granodiorite with the mineral composition of hornblendebiotite, tonalite, adamelite, eroded granite and thermylonite as well as brecciated diorite, quartz diorite, and xenolite of volcanic and sedimentary rocks formed in the Early Cretaceous. Pueh Granite (Kup), has a granite lithology, adamelite of Late Cretaceous age. Sintang intrusion (Toms), has a lithology of gabbro, granodiorite, quartz diorite, tonalite, diorite, gabbro quartz, changed by secondary minerals chlorite, epidote, sericite, and carbonate; the presence of sericite is associated with quartz-chalcopyrite-molybdenite veins with the presence of diffuse pyrite and there is gold mineralization having an Early Oligocene - Early Miocene age.

According to (Daines, 1985; Soeria-Atmadja, Noeradi and Priadi, 1999) occurred rifting in Eocene-Early Oligocene to form the South China Sea. The result of the expansion process causes subduction which results in a southward movement of 
the Continental Block. Tectonic processes that produce magmatic arcs occur in the Eocene-Early Oligocene, which can be seen from Sintang to Kelian along Central Kalimantan.

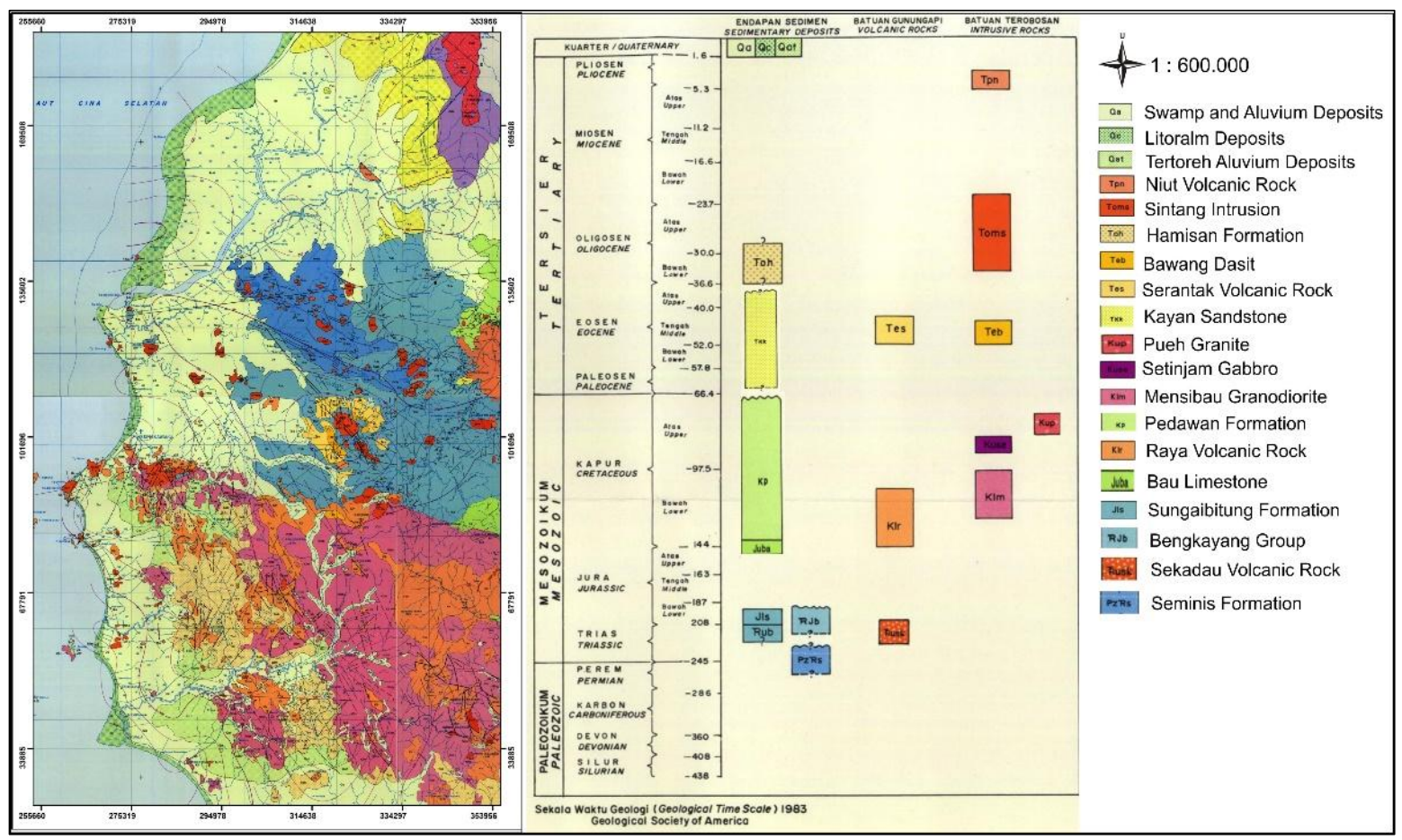

Fig 1. Correlation of Geological Map and Stratigraphy Singkawang, West Kalimantan (Suwarna et al., 1993)

\subsection{Regional Geologi of Karangsambung}

Based on the division of physiographic zone according to (Van Bemmelen, 1949), the study area is a part in the South Serayu Mountains Zone and is located in the southern part of Central Jawa can be seen in fig 2.

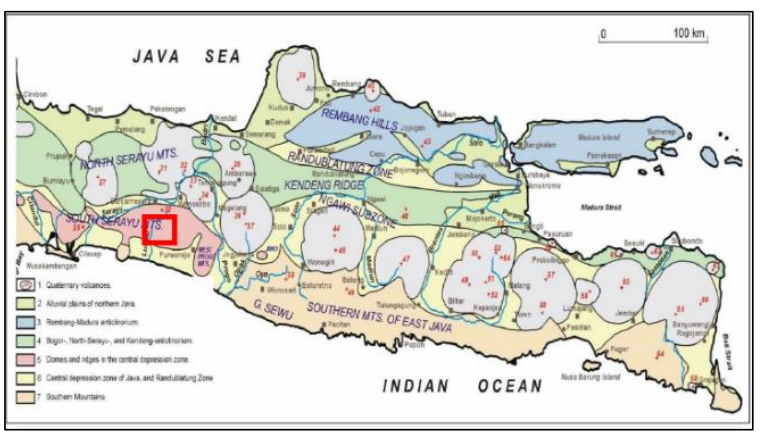

Fig 2. Physiography of Eastern part of Java (Van Bemmelen, 1949)

Based on stratigraphy conditions from (Prasetyadi, 2007) in fig 3, the research are include in Melange Luk Ulo Complex consist of Metamorphic rock, igneous rocks and also pelagic sediment (Asikin et al., 1992)

The subduction process between the Indo-Australian Plate and the micro-Sundanese resulted in the formation of three tectonic patterns on the island of Java. The dominant structures found on the island of Java include the Java pattern with an east-west direction (EW), the Sunda pattern with a north-south direction (NS), and the Meratus pattern with a northeast-southwest direction (NE-SW) with the Javanese pattern as the youngest pattern (Pulunggono and Martodjojo, 1994)

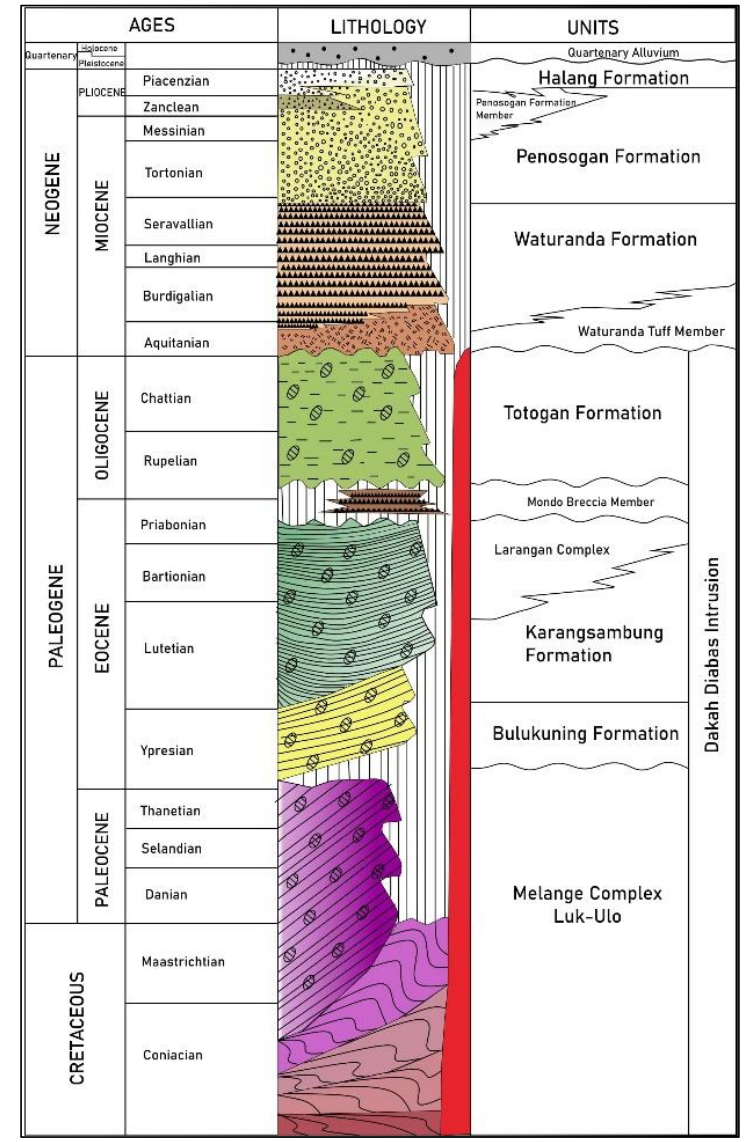

Fig 3. Regional Stratigraphy of Karangsambung (Prasetyadi, 2007) 


\section{Research Methods}

Sampling was carried out in two different areas. Samples in the West Kalimantan area were taken as representatives of the granitoid samples. For the Karangsambung area samples were taken on a representative river flow from the granitoid sample. The methods used in this analysis are petrographic analysis and geochemical analysis.

This petrographic analysis was carried out at the Optical Laboratory of the Geotechnology Research Center, LIPI-Bandung. The sample analysis consisted of 39 samples with details of West Kalimantan rock samples including 2 fresh rock samples and 24 altered rock samples can be seen in fig 4 .

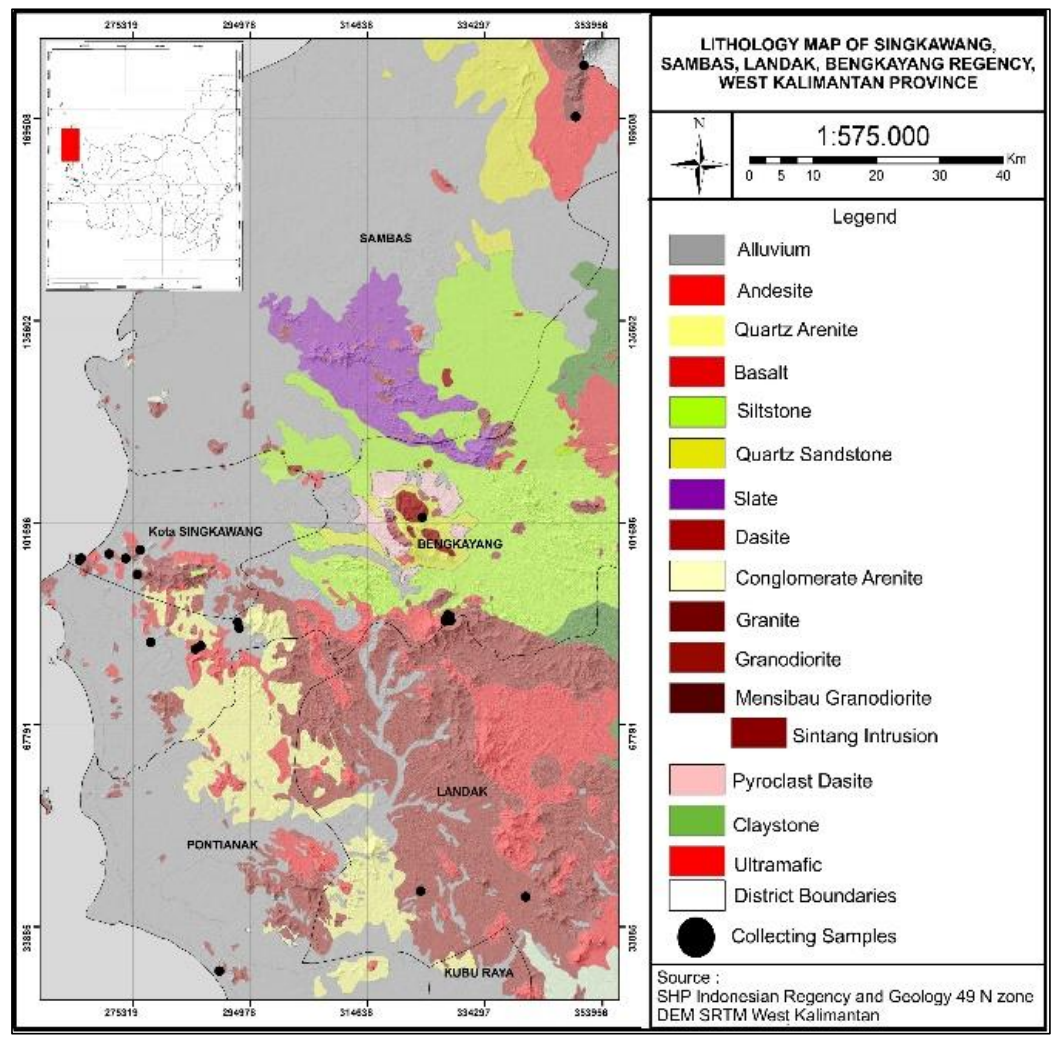

Fig 4. Litology map Research Area of Singkawang, Sambas, Landak, Bengkayang Regency.

Karangsambung rock samples included 13 fresh rock samples can be seen in fig 5. Specifically for West Kalimantan, mineragraphic analysis in the form of polishing sections consists of 4 sample. Geochemical analysis using XRF (X-Ray Fluorescence). XRF analysis of West Kalimantan samples was carried out by Activation Laboratories LTD., Canada. The results of the XRF analysis of West Kalimantan consisted of 14 samples. Due to limited data for the Karangsambung area, we only use secondary data from (Setiawan and Novian, 2015) and (Isyqi, Hastria and Ansori, 2016). The results of this XRF analysis are in the form of rock geochemical data in the form of data on major elements, trace elements, and rare earth elements.

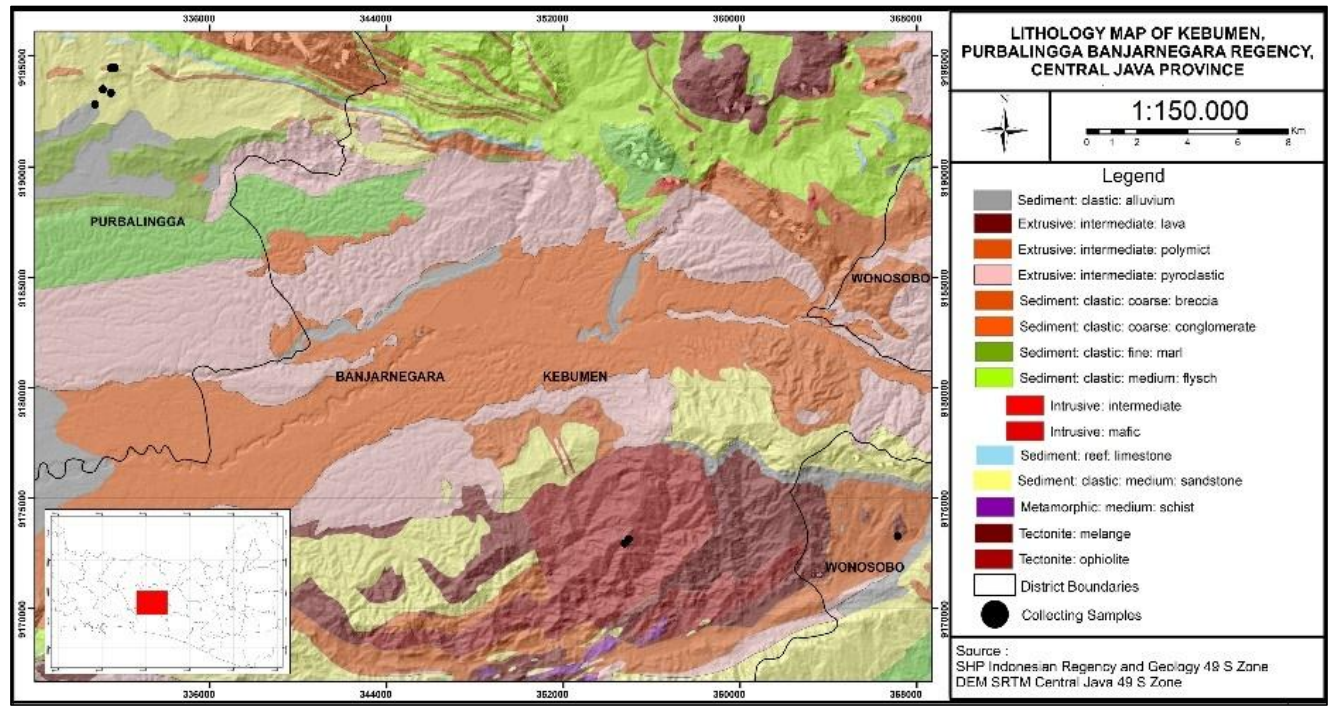

Fig 5. Litology map Research Area of Kebumen, Purbalingga, Banjarnegara Regency 


\section{Results and Discussion}

\subsection{West Kalimantan}

\subsubsection{Petrography}

The results of petrographic observations of the research area produced several characteristics. Mineralogical characteristics have holocrystalline crystallinity, phaneritic granularity, but there are 3 samples that have porphyroafanitic granularity, subhedral crystal form. Most of the samples have undergone quite high rock alteration and deformation. There is a special texture in the form of consertal which has a characteristic indicating that there is intergrowth between quartz and feldspar. As well as the typical micrographic and granophyric where the quartz mineral grows randomly on the feldspar. The main minerals such as quartz, plagioclase, K-feldspar are replaced by secondary minerals in the form of alteration minerals. There are accessory minerals in the form of apatite, zircon, monazite, titanite. The phyllic - propylitic alteration zone.

Based on plotting on the IUGS (Streckeisen, 1976) the analyzed incisions tend to have the name monzogranite except for two incisions, namely sample codes I/080312/M01 and III/110312/M-05 which have the name syenogranite, and alterted stone can be seen in fig 6 .

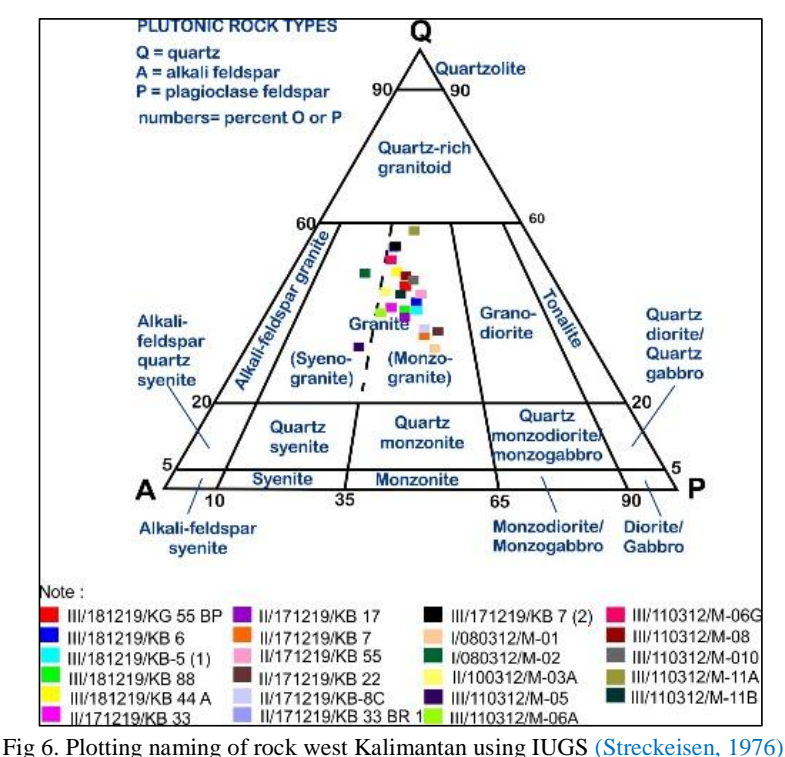

\section{Syenogranite}

This type of naming is only found in two rock samples. With an average mineral composition of $13 \%$ plagioclase, $17 \%$ quartz, $22 \%$ orthoclase, $3 \%$ opaque mineral. With a consertal texture. There is a secondary mineral sericite $40 \%$, secondary quartz $5 \%$. So this rock has undergone quite intense alteration. With selective pervasive alteration style, and moderate alteration intensity of $45 \%$ (Browne, 1991) it belongs to the philic alteration type can be seen fig 7 .

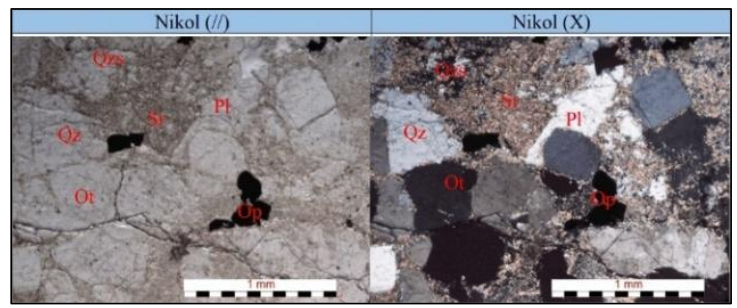

Fig 7. Photomicrograph of synogranite at sample III/110312/M05 with Plagioclase (Pl), Quartz (Qz), Orthoclase (Ot), Clay

$$
\text { (Lm). }
$$

\section{Monzogranite}

This naming type is dominantly found in West Kalimantan rock samples. With a composition of $23 \%$ plagioclase, $30 \%$ quartz, $17 \%$ orthoclase, $18 \%$ biotite, $2 \%$ opaque mineral. With a special texture in the form of concertal, poikilitic, secondary minerals in the form of $20 \%$ epidote. The presence of secondary minerals indicates that this rock has undergone alteration with a style alteration non-pervasive, with a low alteration rate of $20 \%$ (Browne, 1991). Has a propylitic alteration type can be seen in fig 8 .

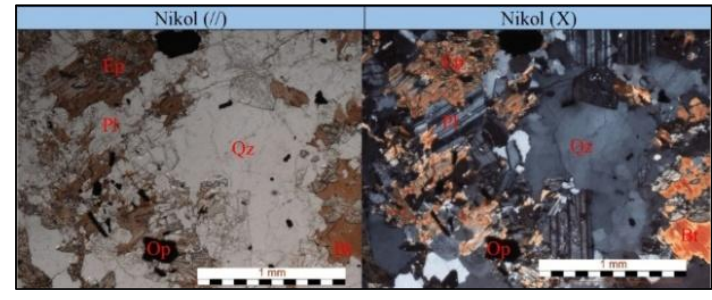

Fig 8. Photomicrograph of Monzogranite at sample II/181219/KG 88 with Plagioclas (Pl), Quartz (Qz), Orthoclas (Ot), Biotiet (Bt), Opaque mineral (Op), Epidote (Ep)

\section{Altered Stone}

This type of naming is based on the appearance on a polarization microscope, the dominance of the main mineral has been replaced but is still granitic. With a composition of $50 \%$ secondary quartz, $35 \%$ base mass, $13 \%$ clay minerals, and $2 \%$ opaque minerals. style alteration Pervasive, with a high intensity level of $100 \%$ alteration (Browne 1991). Based on its appearance, it is included in the silicification alteration type in fig 9 .

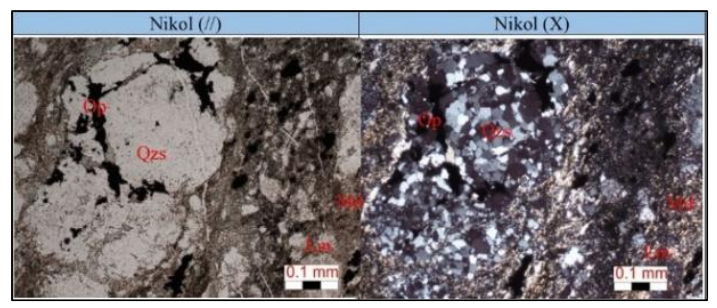

Fig 9. Photomicrograph of altered stone in sample code IV/191219/KB-8with secondary quartz (Qzs), clay minerals (Lm), base mass $(\mathrm{Md})$, opaque minerals (Op) 
The presence of accessory minerals as a marker and can be used as an indicator of petrogenesis. Accessory minerals found in West Kalimantan granitoid samples include zircon, monazite, apatite, titanite can be seen in fig 10 .
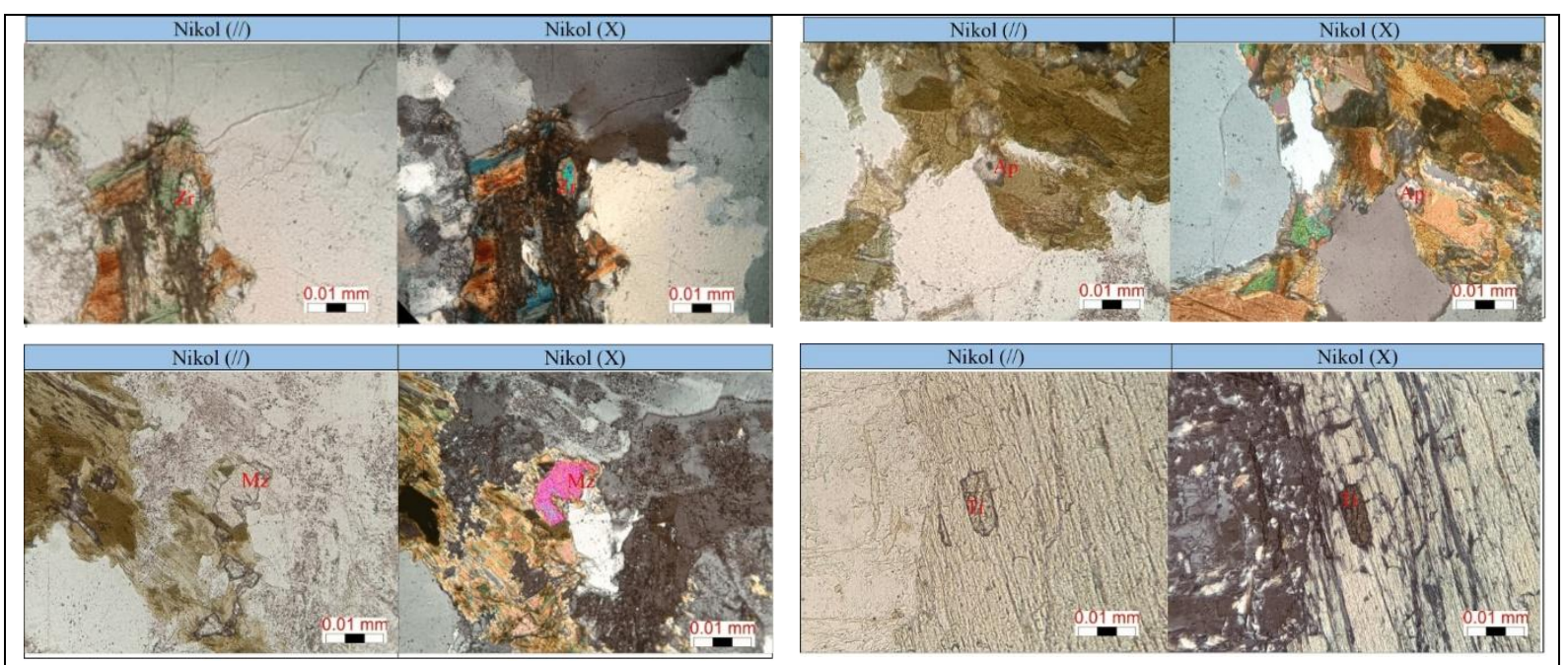

Fig 10. Accessory minerals in sample west Kalimantan. Zircon (Zr), Apatite (Ap), Monazite (Mz), Titantite (Ti)

\subsubsection{Mineragraphy}

Special for sample west Kalimantan doing a mineragraphy analysis. Based on the observation of the optical properties of the rock samples in the study area, they are divided into several groups including native element and sulfide minerals. Native element are founded, namely gold $(\mathrm{Au})$. The appearance of gold $(\mathrm{Au})$ was found with small grains as free grains that did not stick to the others seen in Fig 11.

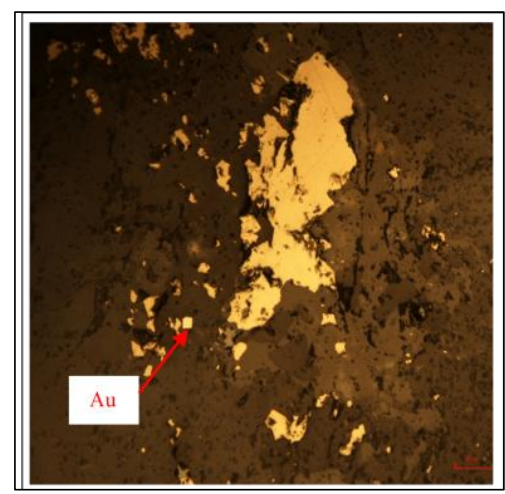

Fig 11. Photomicrograph appearance of native elements with the presence of free grain Au in rock samples code III/181219/KB-6 Bedrock

Based on observations of identified sulfide minerals, namely covelite $(\mathrm{CuS})$, chalcocite $\left(\mathrm{Cu}_{2} \mathrm{~S}\right)$, pyrite $\left(\mathrm{FeS}_{2}\right)$, galena ( $\mathrm{PbS})$, chalcopyrite $\left(\mathrm{CuFeS}_{2}\right)$, bornite $\left(\mathrm{Cu}_{5} \mathrm{FeS}_{4}\right)$, and sphalerite $(\mathrm{ZnS})$ in fig 12.
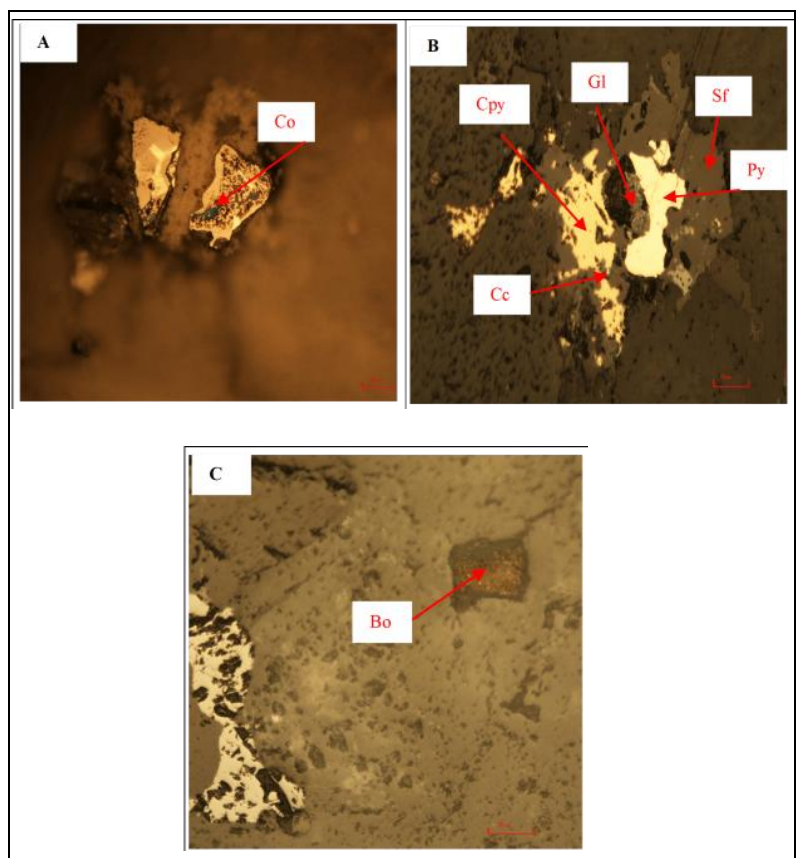

Fig 12. Photomicrographs of the presence of covelite in place of chalcopyrite (cpy) (A), the presence of sphalerite (Sf), pyrite (Py), chalcopyrite (Cpy), galena ( $\mathrm{Gl})$, and chalcocite $(\mathrm{Cc})(\mathrm{B})$, the presence of bornite (Bo) (C), Incision polishing rock code III/181219/KB-7

Ore mineral paragenesis discusses the sequence of ore mineral formation stages. Based on the presence of covelite and chalcocite minerals, the mineralization of the study area has undergone a supergene stage.

Table 1. Mineralization Stage

\begin{tabular}{|c|c|c|c|c|}
\hline \multirow[t]{2}{*}{ Mineral } & \multicolumn{4}{|c|}{ Mineralization Stage } \\
\hline & Early & Middle & Late & Supergen \\
\hline \\
\hline Chalcopyrite & & & & \\
\hline \multicolumn{5}{|l|}{ Sphalerite } \\
\hline \multicolumn{5}{|l|}{ Galena } \\
\hline \multicolumn{5}{|l|}{ Bornite } \\
\hline \multicolumn{5}{|l|}{ Covelite } \\
\hline Calcosite & & & & \\
\hline
\end{tabular}




\subsubsection{Geochemical}

Harker diagram plotting was carried out by comparing the ratio of the main elements on the $\mathrm{Y}$ axis with $\mathrm{SiO} 2$ on the $\mathrm{X}$ axis. Since the study area had undergone quite intense alteration, plotting was carried out at a value of $66 \%$. LoI value (Lost on Ignition) $<2.5$ or quite fresh. The tendency of all elements decreases with the increase in $\mathrm{SiO}_{2}$. Elements $\mathrm{MgO}, \mathrm{Fe}_{2} \mathrm{O}_{3}, \mathrm{TiO}_{2}$ decrease. These three elements are found in mafic minerals. This means that the crystal national fraction runs normally because the main composition of mafic minerals tends to decrease followed by an increase in $\mathrm{SiO}_{2}$. The $\mathrm{CaO}$ element also decreased with the addition of $\mathrm{SiO}_{2}$, and was followed by a relative increase in $\mathrm{Na}_{2} \mathrm{O}$ content. It is interpreted that these two elements are the composition of plagioclase minerals. Due to the decrease in $\mathrm{CaO}$ levels and an increase in the relative levels of $\mathrm{Na}$ but not too significant, it indicates that there is a replacement or substitution between $\mathrm{Ca}$ and $\mathrm{Na}$ components when $\mathrm{SiO}_{2}$ is added can be seen in fig 13 .

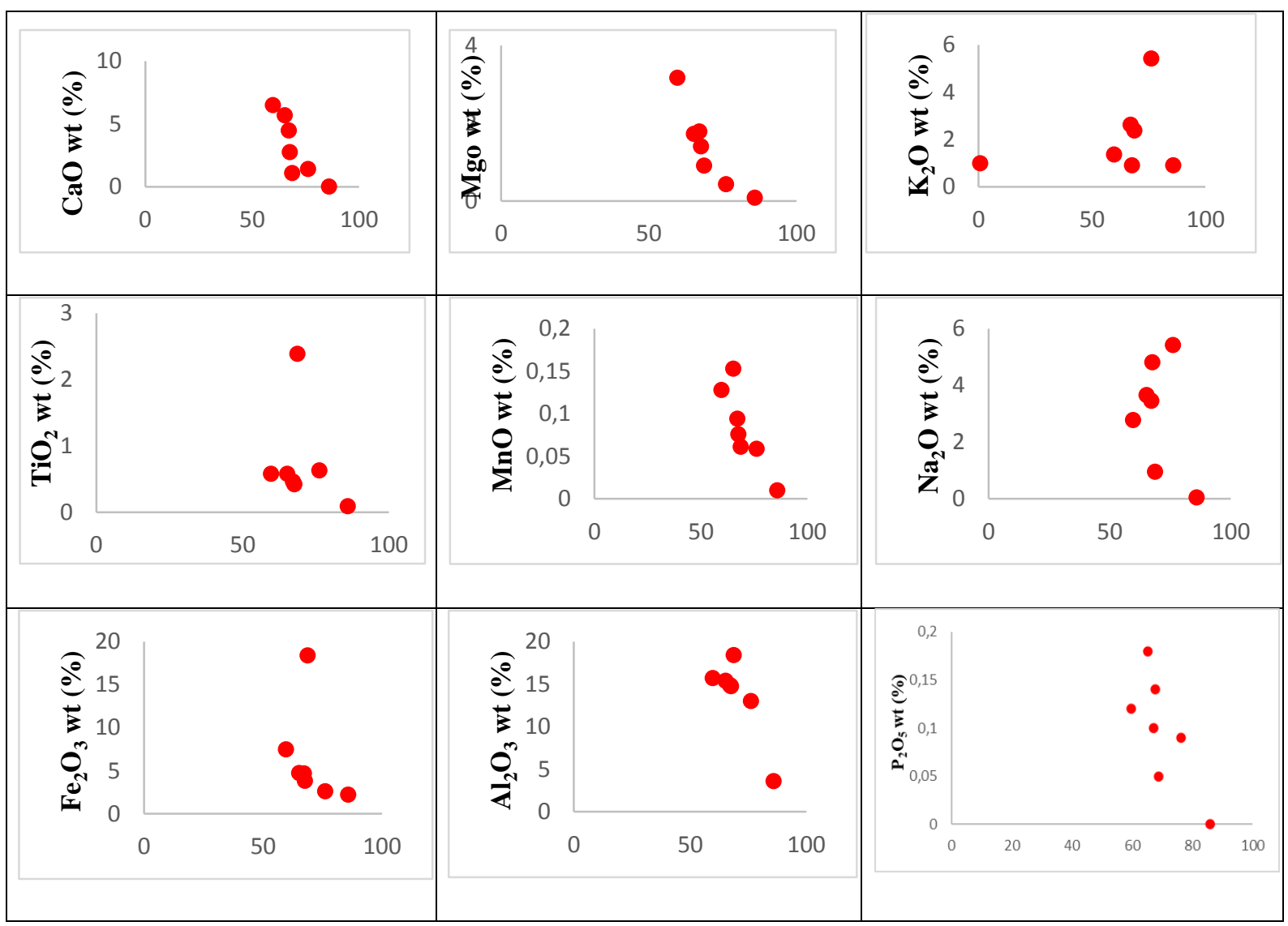

Fig 13. Harker Diagram

Plotting the magma affinity diagram shows that the magma in the granite sample of the study area is formed from magma that is High K Calc Akaline and Calc Alkaline. (Fig 14).

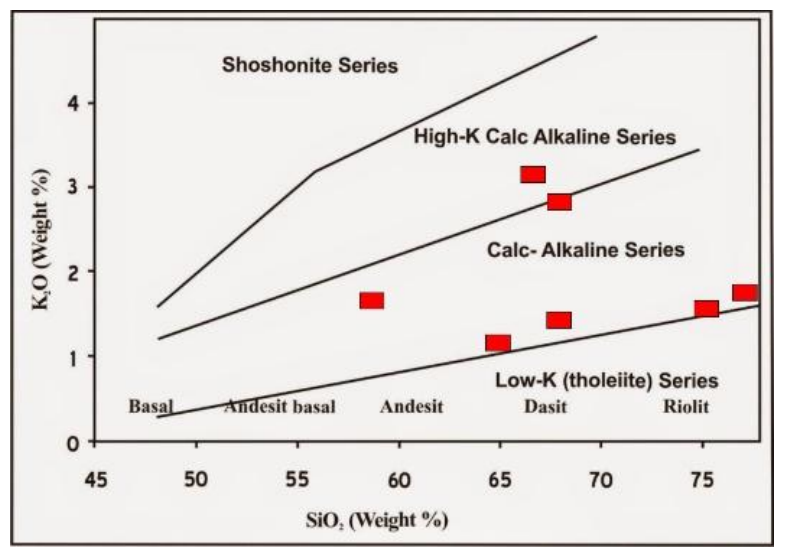

Fig 14. Plotting the classification of rock alkalinity levels (Peccerillo and Taylor, 1976)

The magma type diagram was made by (Chappel and White, 1974) to determine the type of granite which was then used as an indicator of granite petrogenesis parameters. Data is used in the form of moles of each selected main element, namely $\mathrm{Al}_{2} \mathrm{O}_{3}, \mathrm{Na}_{2} \mathrm{O}, \mathrm{CaO}, \mathrm{K}_{2} \mathrm{O}$ can be seen in table 2 .

Based on the results of plotting on the magma type diagram according to (Chappel and White, 1974) the tested granite rock samples have almost the same characteristics 
or transition from metaluminious to peraluminious. $<1.1$ and $>1.1$ then the type of granite in the study area is a mixed type, namely type I granite and type $S$ granite Type I granite implies a source rock of magma composition which is mafic to intermediate or infracrustal derivational (Chappel and
White, 1974; Chappell and Stephens, 1988) can bee seen in fig 15. While this type of $\mathrm{S}$ granite indicates that the source rockis sedimentary rock or protolith crust (supracrast protolith (Chappell and Stephens, 1988).

Table 2. Calculate of mol compound A/NK, nad A/CNK mol value

\begin{tabular}{rrrrrrrr}
\hline $\mathrm{Na}_{2} \mathrm{O}$ & $\mathrm{K}_{2} \mathrm{O}$ & $\mathrm{CaO}$ & $\mathrm{Al}_{2} \mathrm{O}_{3}$ & $\mathrm{CNK}$ & $\mathrm{NK}$ & $\mathrm{A} / \mathrm{NK}$ & $\mathrm{A} / \mathrm{CNK}$ \\
\hline 0,055645 & 0,027979 & 0,080179 & 0,146275 & 0,163802 & 0,083624 & 1,749195 & 0,892993 \\
0,000645 & 0,009787 & 0,000714 & 0,035588 & 0,011147 & 0,010432 & 3,41132 & 3,19272 \\
0,077581 & 0,009787 & 0,049643 & 0,145294 & 0,137011 & 0,087368 & 1,663015 & 1,060458 \\
0,087419 & 0,006702 & 0,025536 & 0,127843 & 0,119657 & 0,094121 & 1,358278 & 1,068412 \\
0,015323 & 0,025426 & 0,019643 & 0,180882 & 0,060391 & 0,040748 & 4,439036 & 2,995189 \\
0,044839 & 0,014681 & 0,115714 & 0,154608 & 0,175234 & 0,05952 & 2,597597 & 0,882294 \\
0,059032 & 0,007766 & 0,101607 & 0,151471 & 0,168405 & 0,066798 & 2,267584 & 0,89944 \\
\hline
\end{tabular}

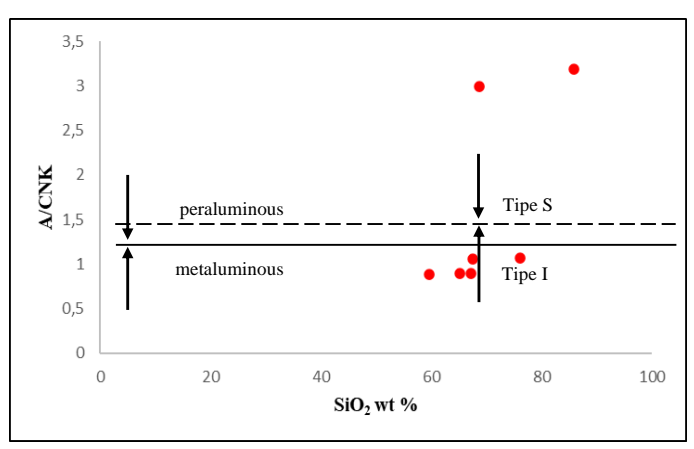

Fig 15. Diagram Type of Granite (Chappel and White, 1974)

This geochemical analysis also produces trace elements and rare rearth elements. For plotting, a normalized chondrite spider diagram and a normalized extend spider diagram of the primitive mantle were used to eliminate the Oddo-Harkins effect.

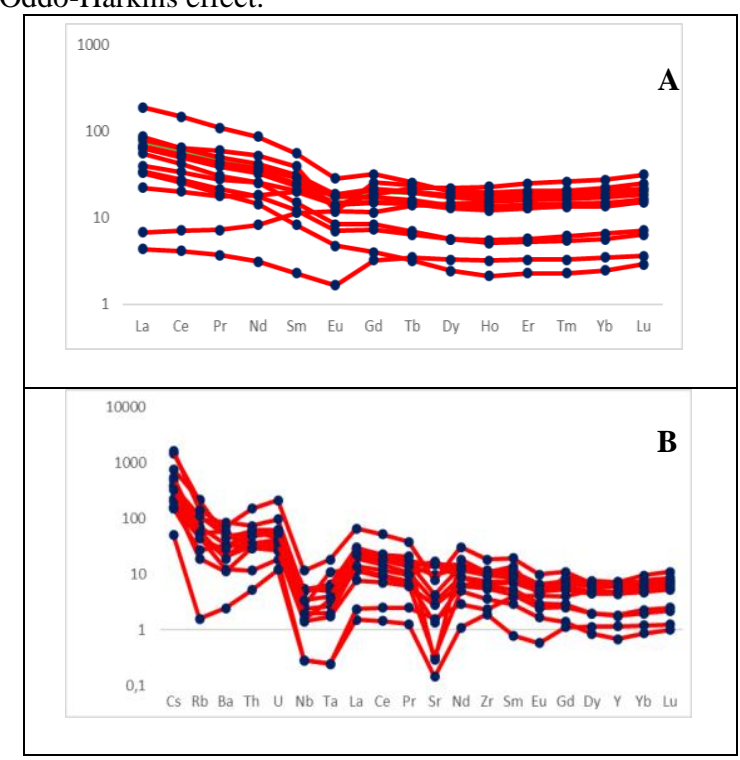

Fig 16. Normalized spider diagram chondrite (A) and Extend Spider diagram primitive mantle (B) (McDonough dan Sun, 1989)

Based on plotting in fig 16 This negative anomaly on the Eu element is related to subduction on the island arc or active continental margin. This negative anomalous pattern in Eu indicates that the granitoid was formed from magma remaining from the frozen solution after the plagioclase separation process (Gromet and Silver, 1987; Widana and Priadi, 2015) The elements $\mathrm{Nb}$, Ta and $\mathrm{Sr}$ tend to be depleted or reduced to LREE. The $\mathrm{Nb}$ element has a negative anomaly. This is interpreted as the tectonic setting is still related to the volcanic arc. Sr element experiencing negative anomaly indicates a change of plagioclase $\mathrm{Ca}$ into plagioclase $\mathrm{Na}$ and K-Feldspar in late fractionation.

Based on the plotting in Aluminum saturation indeks diagram (Shand, 1943) in fig 17 found that samples of rocks scattered on the metaluminous towards peraluminous. When viewed overall, the dominant trend is towards peraliuminous, although there is a metaluminious magma type, so that the rock samples are classified as peraluminious and metaluminious. Tectonic environment ranging from CCG (continental collision granitoids), CAG (continental arc granitoids).

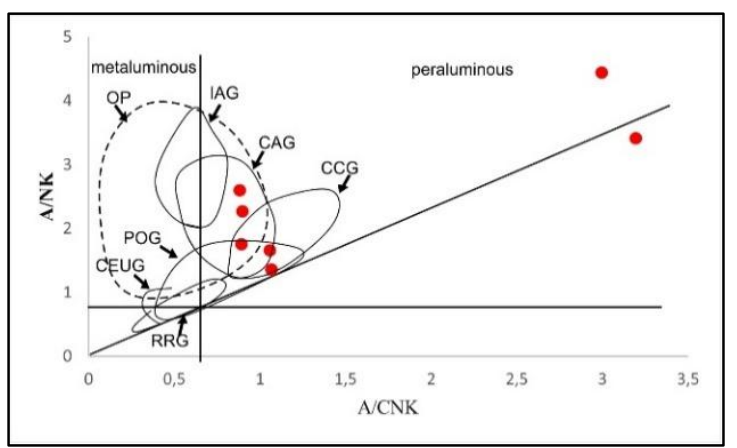

Fig 17. Setting Tectonics using Aluminium Saturation Indeks (Shand, 1943)

\subsection{Karangsambung}

\subsubsection{Petrography}

Mineralogical characteristics based on petrography have holocrystalline crystallinity, phaneritic, granularity, subhedral crystal form. There is a special texture in the form of consertal which has a characteristic indicating that there is intergrowth between quartz and feldspar. Then there is a special texture of pertite caused by the dissolution process to make pertite a phenocryst in K feldspar. As well as a typical antipertite where the quartz mineral grows randomly on the feldspar. The main minerals such as quartz, plagioclase, K-feldspar. There are accessory minerals in the form of apatite, zircon, titanite. Based on plotting on the IUGS Streckeisen classification (1967) the overall analyzed incisions tended to have the name monzogranite can be seen in fig 18. 


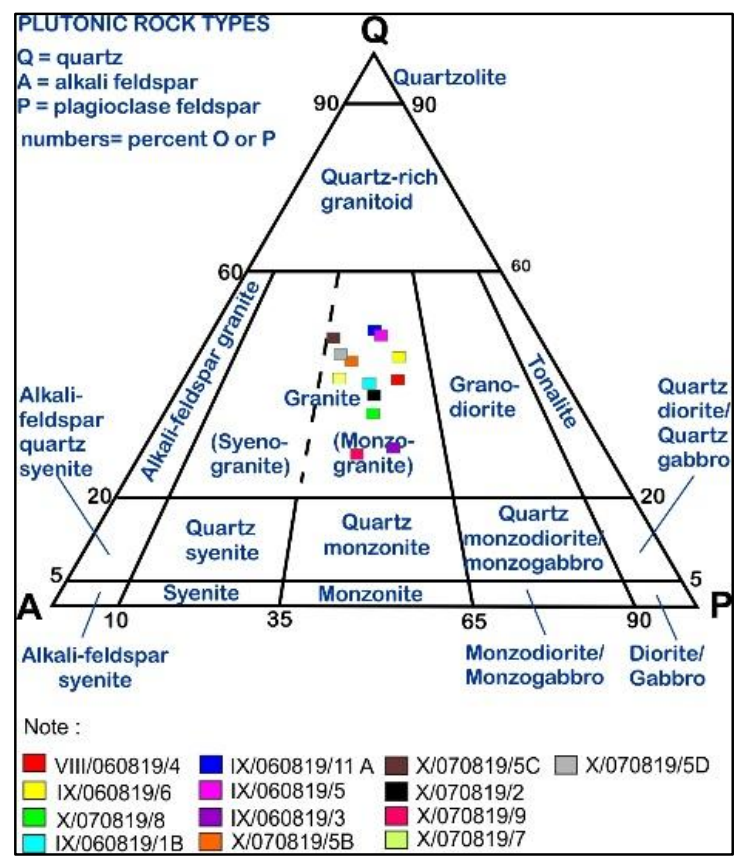

Fig 18. Plotting naming of rock Karangsambung using (Streckeisen, 1976)

\section{Monzogranite}

This type of naming is the naming of the entire granitoid sample being analyzed. Based on petrographic analysis, it has phaneric granularity, holocrystalline crystallinity degree, relationship between hypidiomorphic crystals, special texture in the form of consertal intergrowth, pertite, antipertyte, primary mineral composition in the form of plagioclase (An42) 20\% , quartz 35\%, orthoclase 20\%, muscovite $25 \%$. Can bee seen in fig 19 .

The presence of accessory minerals as a marker and can be used as an indicator of petrogenesis. Accessory minerals found in West Kalimantan granitoid samples include zircon, monazite, apatite, titanite can be seen in fig 20 .

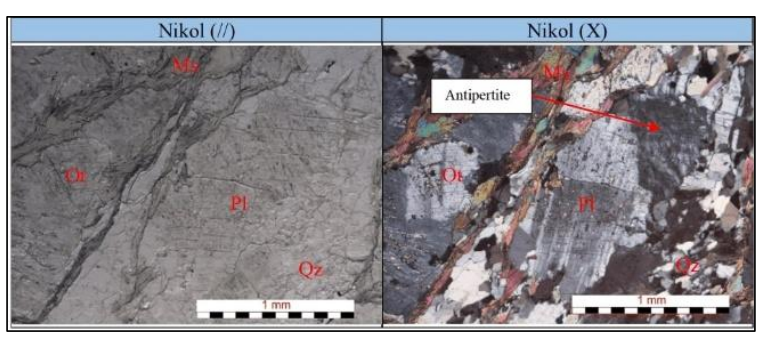

Fig 19. Photomicrograph of the antipertytic texture present on a thin slice of the sample code $\mathrm{X} / 070819 / 5 \mathrm{C}$ with the composition of muscovite $(\mathrm{Ms})$,orthoclase $(\mathrm{Ot})$, plagioclase $(\mathrm{Pl})$, quartz $(\mathrm{Qz})$

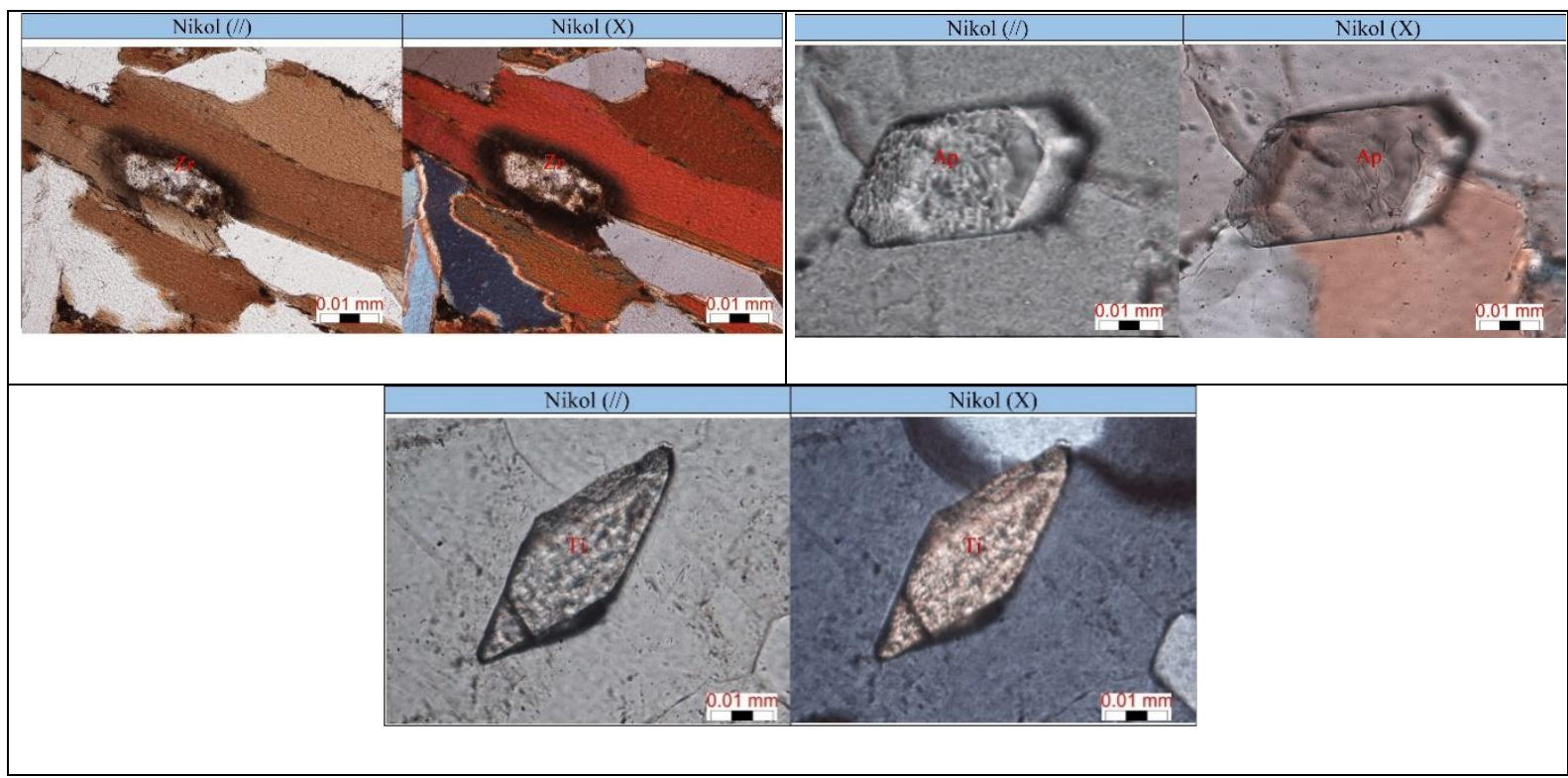

Fig 20. Accessory minerals in sample Karangsambung contains Zircon (Zr), Apatite (Ap), Titantite (Ti)

\subsubsection{Geochemical}

This geochemical analysis compares the data of previous research by (Setiawan and Novian, 2015) with (Isyqi, Hastria and Ansori, 2016). (Isyqi, Hastria and
Ansori, 2016) used 5 samples for geochemical analysis, while (Setiawan, et al 2015) used 11 samples for geochemical analysis. 
Major element used by harker diagram. This analysis uses a Harker diagram by comparing the $\mathrm{SiO}_{2}$ element with other main elements. The plotting of (Setiawan and Novian, 2015) with (Isyqi, Hastria and Ansori, 2016) has pattern trend a relatively similar. It can be seen that the value of $\mathrm{MgO}, \mathrm{Fe}_{2} \mathrm{O}_{3}, \mathrm{TiO}_{2}$ decreased along with the increase in $\mathrm{SiO}_{2}$. If you look at the three elements, it is interpreted that the content is found in mafic minerals. This means that the crystal fractionation is running normally. The $\mathrm{CaO}$ element also decreased with the addition of $\mathrm{SiO}_{2}$, and was followed by a relative increase in $\mathrm{Na}_{2} \mathrm{O}$ content. It is interpreted that these two elements are the composition of plagioclase minerals. For the trend overall, all elements have decreased but some have increased significantly. This can be interpreted to mean that they are still in the same genetic (Mustafa and Usman, 2016) can bee seen in fig 21.

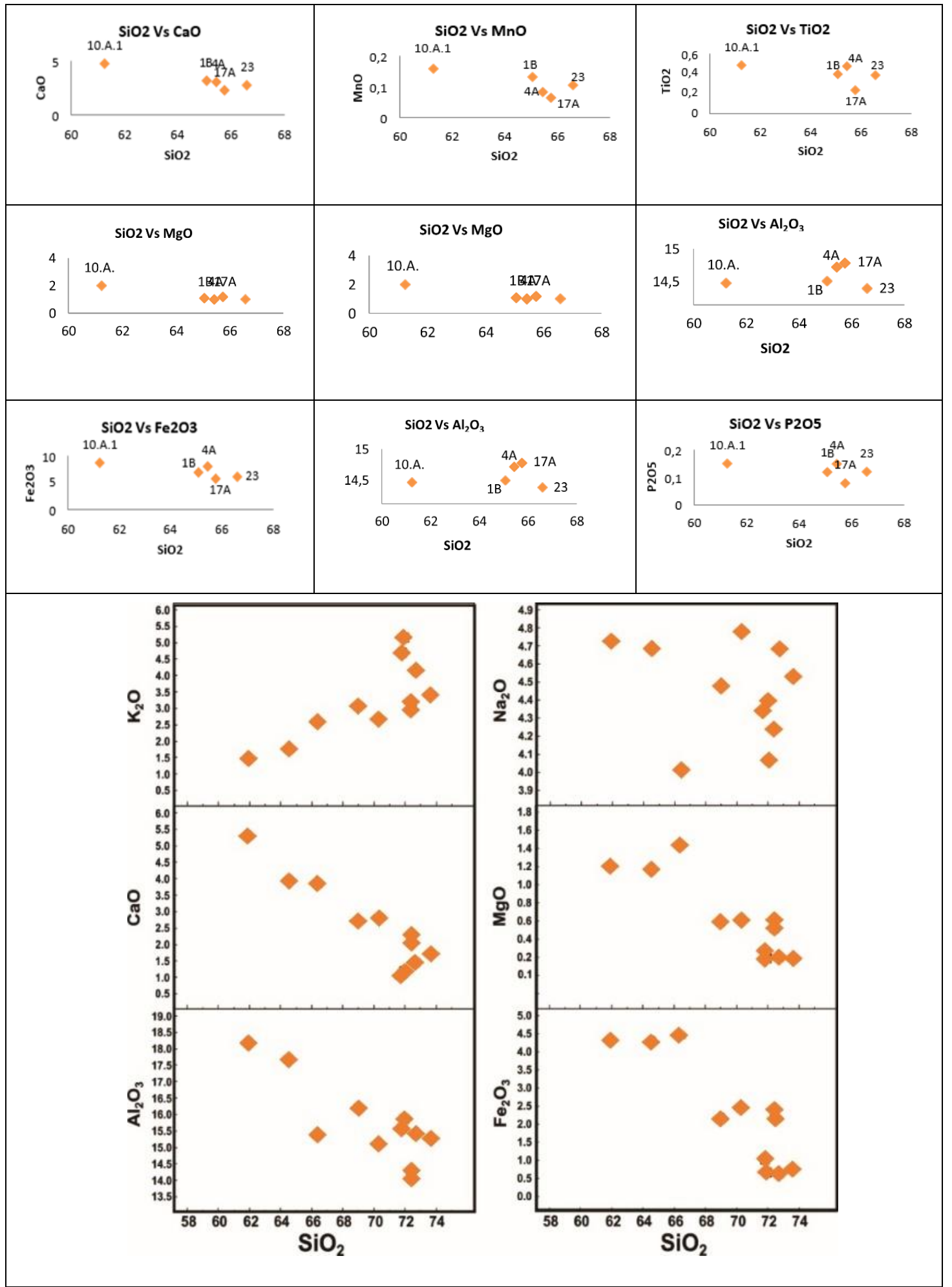

Fig 21. Comparison of the principal elements with $\mathrm{SiO} 2$ on the Harker diagram by (A) (Setiawan and Novian, 2015) (B) (Isyqi, Hastria and Ansori, 2016)

Plotting the magma affinity diagram shows that the magma in the granite sample in the study area is formed from magma that is High K Calc Akaline and Calc Alkaline can be seen in fig 22 . 


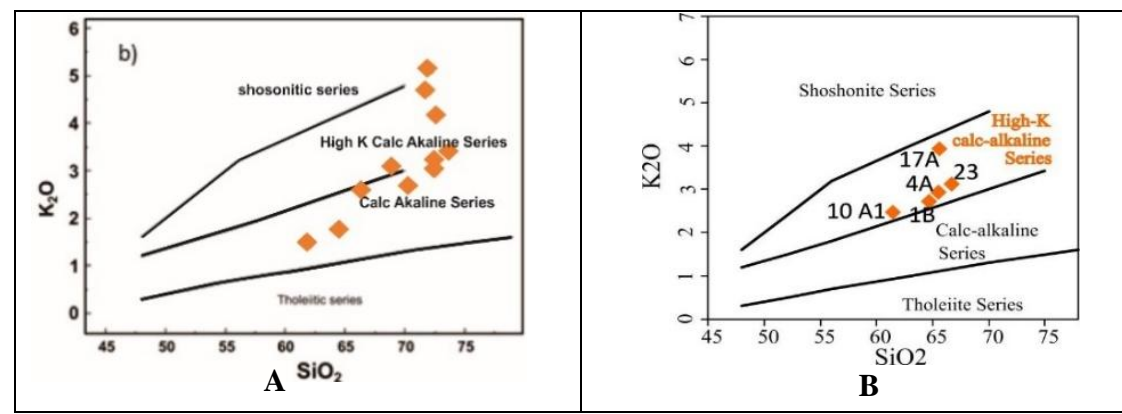

Fig 22. Plotting the classification of rock alkalinity levels by (a) (Setiawan and Novian, 2015) (b) (Isyqi, Hastria and Ansori, 2016) (Peccerillo and Taylor, 1976)

Based on the results of plotting on the magma type diagram according to (Chappel and White, 1974) granite rock samples have almost the same characteristics as metaluminious. this plotting spread but dominant in the metaluminious. For the type of granite, the research area is granite type I. This type of granite indicates that it implies a source rock from magma composition that is mafic to intermediate or infracrustal (Chappell and Stephens, 1988) can be seen in fig 23 .

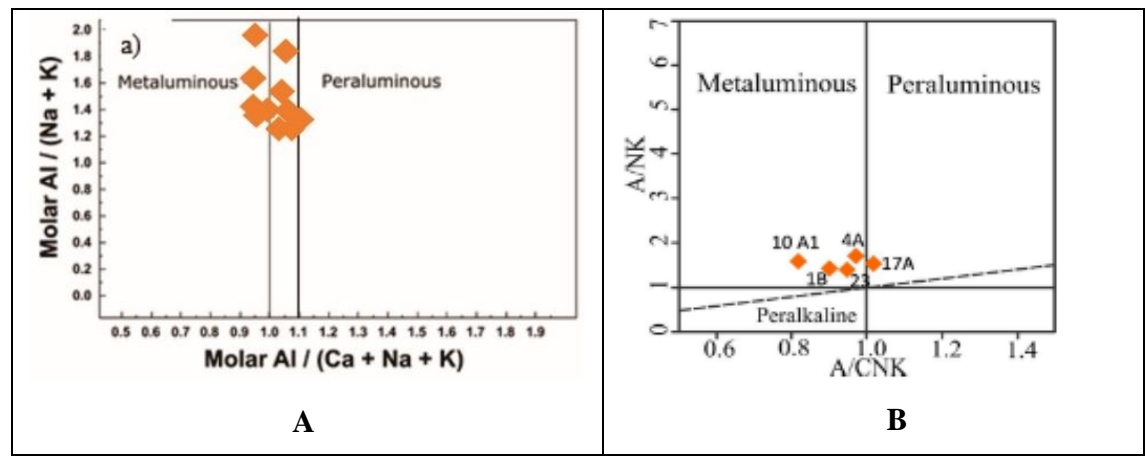

Fig 23. Granite type classification diagram (a) (Setiawan and Novian, 2015) (b) (Isyqi, Hastria and Ansori, 2016) (Chappel and White, 1974)

This geochemical analysis also produces trace elements and rare rearth elements. For plotting, a normalized chondrite spider diagram and a normalized extend spider diagram of the primitive mantle were used to eliminate the Oddo-Harkins effect.

The plot by (Setiawan and Novian, 2015) REE into two, namely enrichment of LREE elements with depleted HREE elements and enriched in LREE accompanied by depleted then enriched again in HREE. There is a position of negative anomalies in $\mathrm{Nb}$ and $\mathrm{Tb}$ element, as well as positive by $\mathrm{Sr}$ anomaly found in all the samples analyzed were randomly can see in fig 24 .

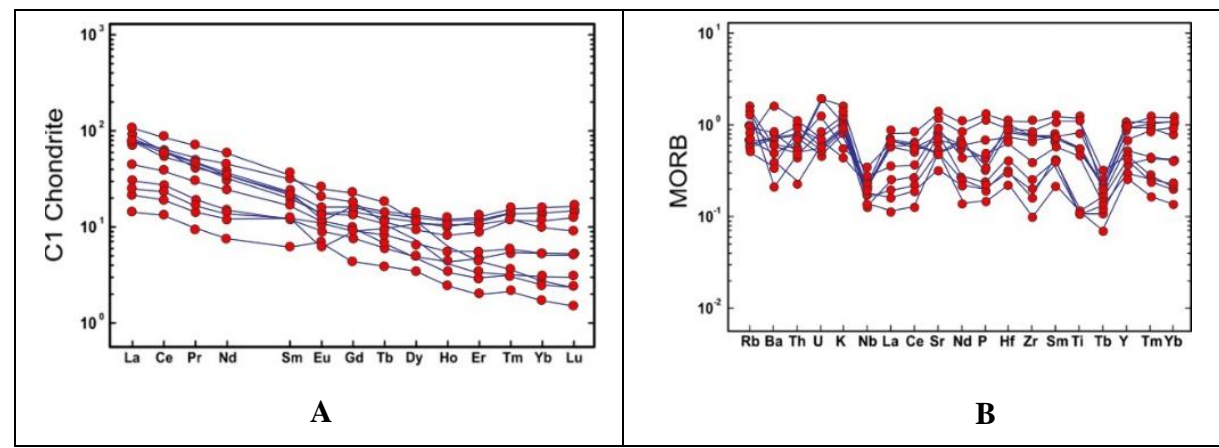

Fig 24. Spider diagram normalized chondrite (A) and Extend Spider diagram primitive mantle (B) by (Setiawan, et al 2015) (McDonough and Sun, 1989)

Based on pengeplotan by (Isyqi, Hastria and Ansori, 2016) on the normalization MORB there is enrichment of elements $\mathrm{K}, \mathrm{Rb}, \mathrm{Ba}, \mathrm{Th}, \mathrm{Ce}$, and $\mathrm{Sm}$, but depleted elements $\mathrm{Ta}, \mathrm{Nb}, \mathrm{P}, \mathrm{Hf}, \mathrm{Zr}, \mathrm{Ti}, \mathrm{Y}$ and $\mathrm{Yb}$. Positive anomalies in low ionic potential incompatible elements such as $\mathrm{K}, \mathrm{Tb}, \mathrm{Ba}$ and Th were caused by the metasomatism process in the mantle of the solution agent which was released in theprocess subduction slab. Then negative anomalies in high ionic potential incompatible elements such as (Ta, $\mathrm{Nb}, \mathrm{P}, \mathrm{Hf}, \mathrm{Zr}$, $\mathrm{Ti}, \mathrm{Y}$ and $\mathrm{Yb}$ caused by theprocess partial melting with a high degree of intensity used in the formation of stable mantle residues (Wilson, 1989). For the normalization of chondrite by (Sun and McDonough, 1989) shows apattern depleted on the element Eu. This negative anomaly in $\mathrm{Eu}$ is related to subduction at the island arc or active continental margin. This negative anomalous pattern on Eu indicates that the granitoid is formed from magma remaining from the frozen solution after the plagioclase separation process (Gromet and Silver, 1987; Widana and Priadi, 2015) in fig 25 . 

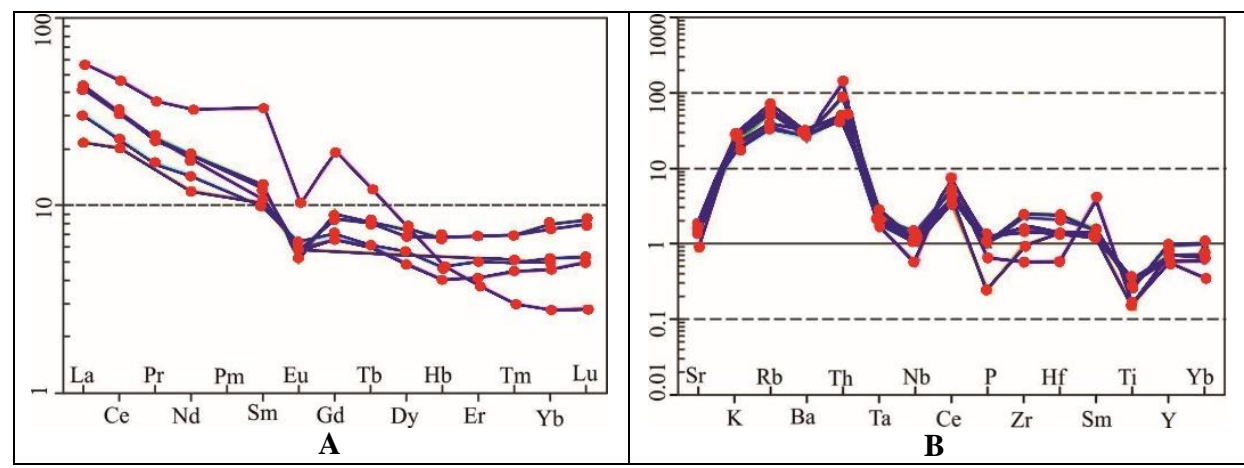

Fig 25. Spider diagram normalized chondrite (A) and Extend Spider diagram primitive mantle (B) by (Isyqi, Hastria and Ansori, 2016) (Sun and McDonough, 1989)

Based on the results of plotting the tectonic discriminant diagram from (Pearce, Harris and Tindle, 1984) from the diagram $(\mathrm{Yb}+\mathrm{Nb})$ vs $\mathrm{Rb}, \mathrm{Y}$ vs $\mathrm{Nb}, \mathrm{Yb}$ vs Ta, it was found that according to (Setiawan and Novian,
2015) and (Isyqi, Hastria and Ansori, 2016) this Karangsambung granitoid has atectonic environment. volcanic arc granite (VAG) can be seen in fig 26.
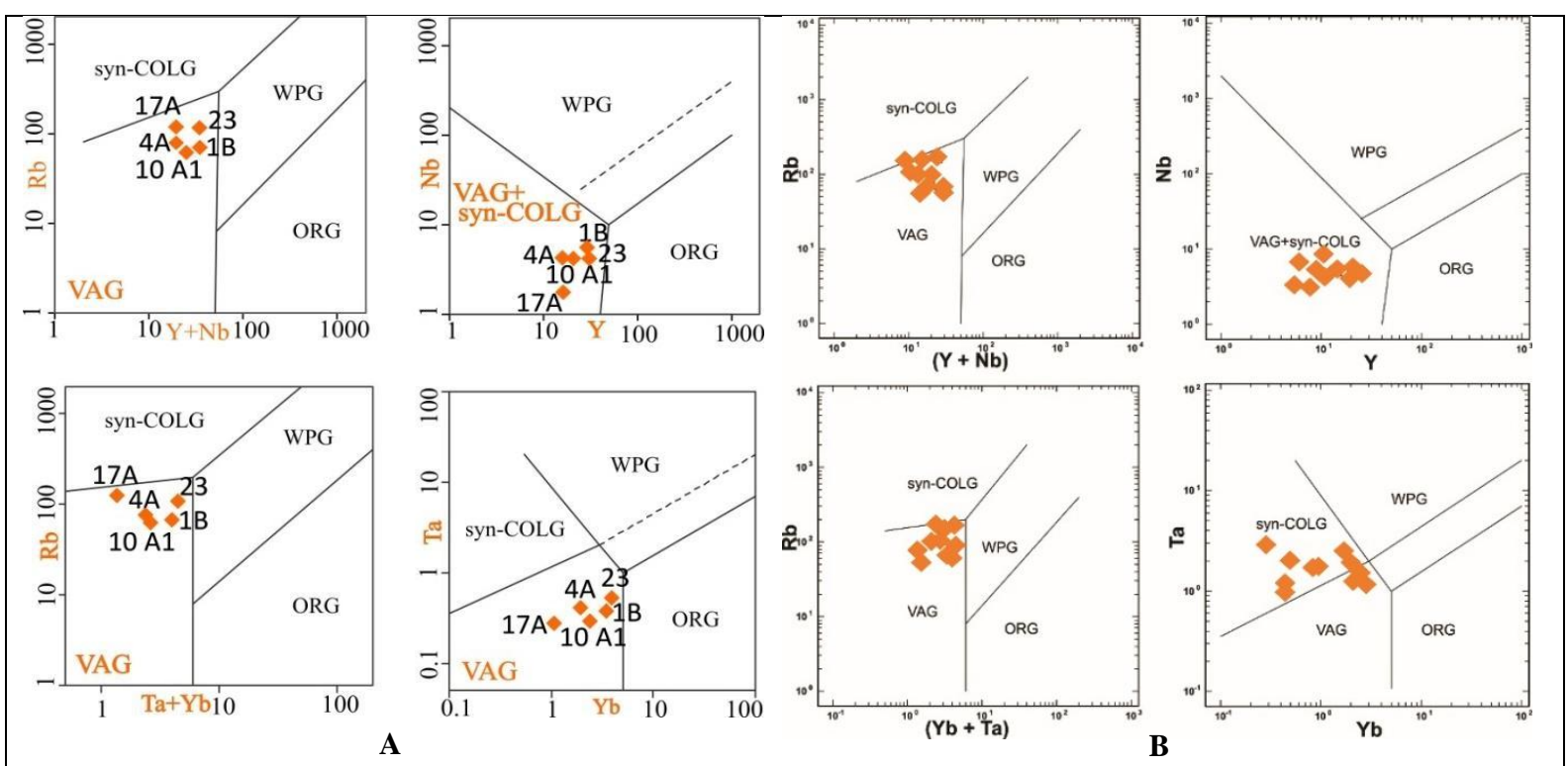

Fig 26. Plotting Discriminant Diagram (a) (Isqy, et al 2016), (b) (Setiawan et al, 2015) (Chappell and White, 1974)

\subsection{Comparison of Granitoid Characteristics}

Analysis has been carried out in the form of study area. Then obtained several comparisons on the samples that have been analyzed from the two research areas can be seen in table 3 .

petrographic analysis, mineragraphy, as well as geochemical analysis of the granite rock samples in the

Table 3. Comparison of Granitoid Characteristics

\begin{tabular}{|c|c|c|}
\hline Parameter & West Kalimantan & Karangsambung \\
\hline Special Textures & $\begin{array}{l}\text { Consertal, poikilitic, } \\
\text { micrographic, granophyric }\end{array}$ & $\begin{array}{l}\text { Consertal, pertite, } \\
\text { antipertite }\end{array}$ \\
\hline Major Minerals & $\begin{array}{l}\text { Quartz, plagioclas, } \\
\text { ortoclas, biotite, hornblenda }\end{array}$ & $\begin{array}{l}\text { Quartz, plagioclas, } \\
\text { ortoclas, biotite }\end{array}$ \\
\hline Accessory Minerals & Zircon, apatite, monazite, titanite & Zircon, apatite, titanite \\
\hline Name of Rocks & $\begin{array}{l}\text { Syenogranite, monzogranite, dan altered } \\
\text { stone }\end{array}$ & Monzogranite \\
\hline Alteration & phylic-Silisification-Propylitic & - \\
\hline Magma Afanity & Calc alkaline- high $K$ calc alkaline series & $\begin{array}{l}\text { Calc alkaline- high } K \text { calc alkaline } \\
\text { series }\end{array}$ \\
\hline Type of Magma & $\begin{array}{l}\text { Metaluminious and } \\
\text { Peraluminious }\end{array}$ & Metaluminious \\
\hline Type of Granite & I Type dan S Type & I Type \\
\hline Setting Tectonics & $\begin{array}{l}\text { Continental Arc Granite } \\
\text { (CAG) dan Continental } \\
\text { Collision Granite }(C C G)\end{array}$ & $\begin{array}{l}\text { Volcanic arc granitoid } \\
(V A G)\end{array}$ \\
\hline
\end{tabular}




\section{Conclusion}

Based on the mineralogical aspects of the petrographic analysis of granite in West Kalimantan and Karangsambung, there is quite a difference. West Kalimantan granite has a specialtexture micrographic, granophyric with altered rock conditions so that it has a phyllic-silicified-propyltic alteration zone. Has three types of naming synogranite, monzogranite, altered stone. With the presence of opaque minerals that can be analyzed for mineralization. The accessory minerals are zircon, moderate apatite, monazite, titanite. Karangsambung granite has a special texture that is typical of perite and antipertyte without the presence of secondary minerals. For the presence of the most accessory minerals, namely zircon. It has thename monzogranite.

Based on geochemical analysis, West Kalimantan granite has an affinity for Calc-High K Calc alkaline, magmawith metaluminious and peraluminious magma types resulting in granite types I and S, interpreted to be formed from different parental magmas. Formed inenvironments continental arc granite (CAG) and continental collision granite (CCG). Geochemistry of Karangsambung granite has an affinity CalcHigh K Calc alkaline, magmawith a metaluminious magma type. So it has type I granite. Formed on volcanic arc granite (VAG).

\section{Acknowledgements}

The author is very grateful to Dr. Eng Iwan Setiawan and Tri Winarno who have helped guide during the writing of this scientific paper. and thanks to Diponegoro University of Geological Engineering for providing the opportunity to conduct this research.

\section{References}

Asikin, S. et al. (1992) 'Peta Geologi Lembar Kebumen, Jawa, Pusat Riset dan Pengembangan Geologi, Indonesia, Skala $1: 100.000$ '

Barbarin, B. (1999) 'A review of the relationships between granitoid types, their origins and their geodynamic environments', Lithos, 46(3), pp. 605-626. doi: 10.1016/S0024-4937(98)00085-1.

Browne, P. R. L. (1991) Hydrotermal Alteration and Geothermal System. Lecture Handout, The University of Auckland.

Chappel, B. W. and White, A. J. R. (1974) 'Two contrasting granite types.', Pacific Geology, 8(2), pp. 173-174. doi: 10.1046/j.1440-0952.2001.00882.x.

Chappell, B. W. and Stephens, W. E. (1988) 'Origin of infracrustal (I-type) granite magmas', Transactions of the Royal Society of Edinburgh: Earth Sciences, 79(2-3), pp. 71-86. doi: 10.1017/S0263593300014139.

Ilmawan, I. (2019) Geologi, Geologi, Alterasi Hidrotermal Dan Mineralisasi Pada Endapan Epitermal Sulfidasi Rendah - Menengah Di Desa Monterado, Kecamatan Monterado, Kabupaten Bengkayang, Provinsi Kalimantan Barat (Skripsi). Departemen Teknik Geologi, Fakultas Teknik, Universitas Gadjah Mada.

Isyqi, Hastria, D. and Ansori, C. (2016) 'Klasifikasi Granitoid Karangsambung Berdasarkan Data Petrografi Dan', Prosiding Geotek Expo Puslit Geoteknologi LIPI,
(October 2017), pp. 978-979.

Mustafa, M. A. and Usman, E. (2016) 'Analisis Perbandingan Geokimia Granit Dan Sedimen Dasar Laut Di Pulau Singkep Bagian Timur, Provinsi Kepulauan Riau', Jurnal Geologi Kelautan, 11(3), p. 131. doi: 10.32693/jgk.11.3.2013.237.

Pearce, J. A., Harris, N. B. W. and Tindle, A. G. (1984) 'Trace element discrimination diagrams for the tectonic interpretation of granitic rocks', Journal of Petrology, 25(4), pp. 956-983. doi: 10.1093/petrology/25.4.956.

Peccerillo, A. and Taylor, S. R. (1976) 'Geochemistry of eocene calc-alkaline volcanic rocks from the Kastamonu area, Northern Turkey', Contributions to Mineralogy and Petrology, 58(1), pp. 63-81. doi: 10.1007/BF00384745.

Prasetyadi, C. (2007) Evolusi Teknik Paleogen Jawa Tengah Bagian Timur (Disertasi Doktor). Institut Teknologi Bandung (Tidak Tertbit).

Pulunggono, A. and Martodjojo, S. (1994) 'Perubahan Tektonik Paleogene - Neogene Merupakan Peristiwa Tektonik Terpenting di Jawa', in Proceeding Geologi dan Geotektonik Pulau Jawa, Percetakan NAFIRI. Yogyakarta, pp. 37-49.

Setiawan, N. I. and Novian, M. I. (2015) 'Petrologi, geokimia dan umur batuan granitoid di komplek luk- ulo, karangsambung, kebumen, jawa tengah', PROCEEDING, SEMINAR NASIONAL KEBUMIAN KE8 Academia-Industry Linkage.

Shand, S. (1943) 'Eruptive Rocks. Their Genesis Composition. Classification, and Their Relation to Ore-Deposits with a Chapter on Meteorite', John Wiley \& Sons, New York.

Soeria-Atmadja, R., Noeradi, D. and Priadi, B. (1999) 'Cenozoic magmatism in Kalimantan and its related geodynamic evolution', Journal of Asian Earth Sciences, 17(1-2), pp. 25-45. doi: 10.1016/S0743-9547(98)000622.

Streckeisen, A. (1976) 'To each plutonic rock its proper name', Earth Science Reviews, 12(1), pp. 1-33. doi: 10.1016/0012-8252(76)90052-0.

Sun, S. S. and McDonough, W. F. (1989) 'Chemical and isotopic systematics of oceanic basalts: Implications for mantle composition and processes', Geological Society Special Publication, 42(1), pp. 313-345. doi: 10.1144/GSL.SP.1989.042.01.19.

Suwarna, N. de Keyser, R. Langford, R.P. Trail, D.S (1993) 'Geologi Lembar Singkawang, Kalimantan, skala $1: 200.000$ '

Widana, K. S. and Priadi, B. (2015) 'Karakteristik Unsur Jejak Dalam Diskriminasi Magmatisme Granitoid Pulau Bangka', Eksplorium, 36(1), p. 1. doi: 10.17146/eksplorium.2015.36.1.2766.

Wilson, B. M. (1989) Igneous Petrogenesis A Global Tectonic Approach. 1st edn. Springer Netherlands. doi: 10.1007/978-1-4020-6788-4.

Van Bemmelen, R. W. (1949) 'The Geology of Indonesia. General Geology of Indonesia and Adjacent Archipelagoes', Government Printing Office, The Hague, pp. 545-547; 561-562.

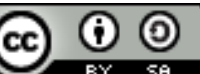

(C) 2021 Journal of Geoscience, Engineering, Environment and Technology. All rights reserved. This is an open access article distributed under the terms of the CC BY-SA License (http://creativecommons.org/licenses/by-sa/4.0/). 